\title{
Synonymy of Pseudomonas coronafaciens, Pseudomonas coronafaciens pathovar zeae, Pseudomonas coronafaciens subsp. atropurpurea, and Pseudomonas striafaciens
}

\author{
N. W. SCHAAD AND B. M. CUNFER \\ Department of Plant Pathology, University of Georgia, Georgia Experiment Station, Experiment, Georgia \\ 30212
}

\begin{abstract}
Eleven strains of Pseudomonas coronafaciens, four strains of $\boldsymbol{P}$. coronafaciens pathovar zeae, six strains of $P$. coronafaciens subsp. atropurpurea, two strains of $P$. striafaciens, and one Pseudomonas sp. were compared by physiological, biochemical, serological, and pathological tests. All strains tested utilized sucrose, glucose, fructose, glycerol, and caprate as sole carbon sources, hydrolyzed Tween 80 , reduced litmus milk, and grew at $0^{\circ} \mathrm{C}$. All strains were arginine dihydrolase and oxidase negative and all strains failed to hydrolyze starch, reduce nitrate, or grow at $41^{\circ} \mathrm{C}$. Cells of all strains were immunofluorescent positive when stained by the indirect immunofluorescence test with antiserum to cells of $P$. coronafaciens or $P$. coronafaciens subsp. atropurpurea. No differences among strains were detected in test tube agglutination tests. No significant differences were detected in the susceptibility of Avena sativa (oats), Secale cereale (rye), Triticum aestivum (wheat), Hordeum vulgare (barley), Bromus inermis (smooth bromegrass), B. japonicus (Japanese brome), B. secalinus (chess brome), $B$. tectorum (cheatgrass), Agropyron repens (quackgrass), Zea mays (maize), or Phleum pratense (timothy) to the different strains. All strains produced toxin in Wooley medium except $P$. striafaciens and strains of $P$. coronafaciens subsp. atropurpurea from Italian ryegrass. The present division of strains of $P$. coronafaciens based on minor differences in pathogenicity and symptomology is untenable.
\end{abstract}

Plant pathogenic bacteria have been classified traditionally into numerous species and subspecies on the basis of their pathogenicity to different hosts. In the 7th edition of Bergey's Manual of Determinative Bacteriology (3) there are 89 species of Pseudomonas listed attacking plants in 49 families. Pseudomonas coronafaciens was described by Elliott in 1920 (10) as the causal agent of halo blight of oats (Avena sativa L.). Three years later Reddy and Godkin (31) described a new bacterial disease of smooth bromegrass (Bromus inermis Leyss) and named the causal bacterium Bacterium coronafaciens var. atropurpureum. Stapp later changed the name to Pseudomonas coronafaciens var. atropurpurea (36). Reddy and Godkin's reasons for naming a new subspecies were that (i) $P$. coronafaciens (from oats) did not infect Bromus iner$m i s$ and (ii) the lesions produced on oats by the two organisms were different. They stated that the two organisms were identical morphologically and physiologically. The name $P$. striafaciens was introduced in 1927 by Elliott (11) as a hitherto undescribed species on the basis of the difference in types of lesions produced on oats and the smaller size of $P$. striafaciens cells in comparison to $P$. coronafaciens. Both organisms attacked the same hosts, gave the same results in host cultivar tests, and were identical culturally and physiologically. Although a type strain was not designated for $P$. striafaciens, Elliott's strain 70 was deposited in the American Type Culture Collection (ATCC) as strain 10730. All three bacteria are listed in the 7 th edition of Bergey's Manual and are included in the First Draft of Approved List of Names (1) requested by the Judicial Commission of the International Committee on Systematic Bacteriology. In the 8th edition of Bergey's Manual, P. coronafaciens is included provisionally in the $P$. syringae group, and $P$. striafaciens is listed among nomenspecies which have been incompletely described (5). Pseudomonas coronafaciens subsp. atropurpurea is not listed. Tessi (40) studied the pathology and toxin-producing abilities of $P$. coronafaciens and $P$. striafaciens on oats in Argentina. He concluded that $P$. striafaciens strains were $P$. coronafaciens strains that had lost the ability to produce toxin. However, he refrained from combining the two species (40). Recently, Ribeiro et al. (32) designated $P$. coronafaciens infecting maize and timothy in Wisconsin as $P$. coronafaciens pathovar zeae on the basis of pathogenicity on maize, timothy, and 
oats and similar physiological characters.

There is need for a reexamination of the taxonomy of $P$. coronafaciens including all currently recognized variants of this species. For this purpose cultural, physiological, serological, and pathological analyses of 23 strains of the four bacteria, including lectotype strain ATCC 10730 (Elliott's strain 70) of $P$. striafaciens, were performed.

\section{MATERIALS AND METHODS}

Bacterial strains. The sources and designations of the 23 strains of $P$. coronafaciens and eight other pseudomonads used in this study are given in Table 1. All cultures were maintained by monthly transfer on King medium $\mathrm{B}$ agar (KB) slants (16) at 2 to $3^{\circ} \mathrm{C}$ and freeze-dried for long-term storage.

Cultural and morphological properties. The media used for determining cultural characteristics were KB and Difco nutrient agar (NA). All media were sterilized for $20 \mathrm{~min}$ at $121^{\circ} \mathrm{C}$ and at a pressure of $1.1 \mathrm{~kg} / \mathrm{cm}^{2}$. Cell morphology was recorded from light microscope observations of Gram-stained smear preparations and from electron microscope observations. Flagella were observed by light microscopy following the methods of Blenden and Goldberg (2) and by electron microscopy using shadowed preparations.

Physiological and biochemical properties. For

TABLE 1. List of strains used in the study of the taxonomy of Pseudomonas coronafaciens

\begin{tabular}{|c|c|c|c|c|}
\hline \multirow{2}{*}{$\begin{array}{l}\text { Laboratory } \\
\text { no. }\end{array}$} & \multicolumn{2}{|l|}{ Received as: } & \multirow{2}{*}{ Source $^{a}$} & \multirow{2}{*}{ Original host } \\
\hline & Name & Strain & & \\
\hline C-19 & $P$. coronafaciens & Original & & Oats (Avena sativa) \\
\hline C-20 & $P$. coronafaciens & Original & & Oats \\
\hline C-23 & $P$. coronafaciens & Original & & Oats \\
\hline $\mathrm{C}-28$ & $P$. coronafaciens & ATCC 19607 & (1) & Oats \\
\hline C-72 & $P$. coronafaciens & NCPPB 1348 & (2) & Oats \\
\hline C-73 & $P$. coronafaciens & NCPPB 1357 & (2) & Oats \\
\hline C-81 & $P$. coronafaciens & NCPPB 1327 & (2) & Rye (Secale cereale) \\
\hline $\mathrm{C}-83$ & $P$. coronafaciens & NCPPB 600 & (2) & Oats \\
\hline C-86 & $P$. coronafaciens & Original & & Rye \\
\hline C-107 & $P$. coronafaciens & Original & & Rye \\
\hline C-117 & $P$. coronafaciens & Original & & Rye \\
\hline C- 162 & $P$. coronafaciens pathovar zeae & ChS-1 & (8) & Maize (Zea mays) \\
\hline C- 163 & $P$. coronafaciens pathovar zeae & ChS-2 & (8) & Maize \\
\hline C- 164 & $P$. coronafaciens pathovar zeae & ChS-3 & (8) & Maize \\
\hline C- 165 & $P$. coronafaciens pathovar zeae & $\mathrm{Ti}-1$ & (8) & Timothy (Phleum pratense) \\
\hline C-82 & $\begin{array}{l}\text { P. coronafaciens subsp. atropurpu- } \\
\text { rea }\end{array}$ & NCPPB 1768 & (2) & Agrostis sp. \\
\hline C-136 & $\begin{array}{l}\text { P. coronafaciens subsp. atropurpu- } \\
\text { rea }\end{array}$ & NCPPB 1769 & (2) & $\begin{array}{l}\text { Tall oatgrass (Arrhenatherum } \\
\text { elatius) }\end{array}$ \\
\hline C-142 & $\begin{array}{l}\text { P. coronafaciens subsp. atropurpu- } \\
\text { rea }\end{array}$ & NCPPB 1328 & (2) & Bromus sp. \\
\hline C-159 & $\begin{array}{l}\text { P. coronafaciens subsp. atropurpu- } \\
\text { rea }\end{array}$ & $\mathrm{Pl}-6-1$ & (7) & $\begin{array}{l}\text { Italian ryegrass (Lolium } \mathrm{mul} \text { - } \\
\text { tiflorum) }\end{array}$ \\
\hline C-160 & $\begin{array}{l}\text { P. coronafaciens subsp. atropurpu- } \\
\text { rea }\end{array}$ & NO55-1 & (7) & Italian ryegrass \\
\hline C-161 & $\begin{array}{l}\text { P. coronafaciens subsp. atropurpu- } \\
\text { rea }\end{array}$ & NO90-1 & (7) & Italian ryegrass \\
\hline C-137 & $P$. striafaciens & $\begin{array}{lr}\text { NCPPB } & 1898 \\
& (\text { ATCC } \\
10730)\end{array}$ & (2) & Oats \\
\hline C-174 & P. striafaciens & $\begin{array}{l}\text { NCPPB } 2394 \\
\text { (Pl-19-1) }\end{array}$ & (2) & Oats \\
\hline $\mathrm{C}-80$ & Pseudomonas sp. & NCPPB 2390 & (2) & Timothy \\
\hline $\mathrm{C}-7$ & $P$. syringae & B-3 & (3) & Peach (Prunus persica) \\
\hline C-18 & $P$. andropogonis & & (4) & Maize \\
\hline C-78 & P. andropogonis & Original & & Sorghum (Sorghum vulgare) \\
\hline C-50 & P. lachrymans & ATCC 11965 & (5) & Cucumber (Cucumis sativus) \\
\hline C-91 & P. aeruginosa & D-5759 & (6) & \\
\hline C-92 & P. cepacia & $\mathrm{KC}-1372$ & (6) & \\
\hline C-94 & P. fluorescens & KC-678 & (6) & \\
\hline C-132 & P. setariae & ATCC 19882 & (1) & \\
\hline
\end{tabular}

"(1) American Type Culture Collection (ATCC), Rockville, Md.; (2) National Collection of Plant Pathogenic Bacteria (NCPPB), Harpenden, Hertfordshire, England; (3) H. English, University of California, Davis; (4) A. Ullstrup, Purdue University; (5) R. W. Goth, U.S. Department of Agriculture, Beltsville, Md.; (6) R. E. Weaver, Center for Disease Control, Atlanta, Ga.; (7) K. Nishiyama, National Institute of Agricultural Science, Tokyo, Japan; (8) R. D. Durbin, University of Wisconsin, Madison. 
carbon source utilization, the methods of Palleroni and Doudoroff were utilized (27). Malonate tests were performed by the methods of Edwards and Ewing (9), except that incubation was at $25^{\circ} \mathrm{C}$ and results were read after 3 days. Growth at 0 and $41^{\circ} \mathrm{C}$ was determined by streaking $\mathrm{KB}$ slants and incubating them in ice in a cold room and at $41^{\circ} \mathrm{C}$ in a Hotpack incubator (model 351910), respectively. Nitrate reduction, starch hydrolysis, and litmus milk reaction were determined by the methods of Kiraly et al. (17). The methods of Stanier et al. (35) were used to test for oxidase and gelatin liquefaction. Lipid hydrolysis was determined in Difco nutrient broth containing sodium chloride. Melanin pigment production was determined in an $\mathrm{L}$ tyrosine agar medium by the method of French and Sequeira (12). Lecithinase hydrolysis was performed by the NA, egg yolk method of Colwell (7) except that the egg yolk suspension was filtered through cheese cloth, then through $8.0-, 3.0-, 0.45-$, and $0.3-\mu \mathrm{m}$ nonsterile membrane filters (Millipore Corp.), and finally through a $0.22-\mu \mathrm{m}$ sterile Millipore filter. Most nutritional tests were chosen because of their previous use in characterizing fluorescent plant pathogenic pseudomonads $(23,33)$.

Serological tests. Inject antigens from Pseudomonas coronafaciens $\mathrm{C}-107$ and $P$. coronafaciens subsp. atropurpurea C-136 were prepared by harvesting the cells from 72-h KB agar slopes in $6 \mathrm{ml}$ of sterile $0.85 \%$ sodium chloride (saline). The suspension was adjusted to 100 Klett units and made $2 \%$ Formalin, and $1 \mathrm{ml}$ was emulsified with $1 \mathrm{ml}$ of Difco incomplete adjuvant by using a high-speed stirrer. Rabbits were given four intramuscular injections at 10-day intervals. The animals were bled 7 days after the last injection, and the sera were stored at $-20^{\circ} \mathrm{C}$.

Tube agglutination tests, using somatic antigens (cells treated at $100^{\circ} \mathrm{C}$ for $1 \mathrm{~h}$ ), were done following the methods of Carpenter (6). Smears for the indirect fluorescent antibody stain were made from a suspension of cells in $10 \%$ Formalin- $0.85 \%$ saline. The smears were made on multiwell slides (Cell-Line Associates, Inc., Minotola, N.J.) with a $0.001-\mathrm{ml}$ loop. After drying, the smears were fixed with Kirkpatrick fixative $(60 \%$ ethanol, $30 \%$ chloroform, $10 \%$ Formalin), stained with the antiserum, and counterstained with a fluorescent anti-rabbit globulin (GIBCO Diagnostics, Grand Island, N.Y.) as described by Goldman (13). Antiserum and anti-rabbit globulin were diluted $1: 4$ and 1:16, as determined by results of a block test (12). After rinsing in phosphate-buffered saline $(\mathrm{pH} 8.0)$ and distilled water, the slides were air-dried and mounted in $0.5 \mathrm{M}$ carbonate-buffered ( $\mathrm{pH} 9.0$ ) glycerin (41). Slides were observed with a Zeiss fluorescence microscope (40X objective) equipped with a BG 12 excitation and 50 barrier filter. The intensity of the fluorescence was classified from $(-)$ to +3 , with $(-)$ representing no visible fluorescence and +3 indicating intense fluorescence.

Pathogenicity tests. Cells were grown overnight at 23 to $25^{\circ} \mathrm{C}$ in medium 523 (15) on a rotary shaker, adjusted to 50 Klett units, and diluted to $10^{-2}$ with sterile distilled water. Test plants were inoculated by injecting the cell suspension into the youngest leaves using a 25-gauge needle and 1.0-ml syringe. Plants were incubated for 4 to 12 days in a greenhouse at 20 to $27^{\circ} \mathrm{C}$. Plant species used for pathogenicity tests were: Secale cereale (rye) "Vitagraze," Avena sativa (oats) "Coker 66-22," Triticum aestivum (wheat) "Holley," Hordeum vulgare (barley) "Volbar," Agropyron repens (quackgrass), Phleum pratense (timothy) "Timfor," Zea mays (maize) "Pioneer 3030," Bromus inermis (smooth brome) "Sac," Bromus japonicus (Japanese brome) PI 239720, Bromus secalinus (chess brome) PI 235612, and Bromus tectorum (cheatgrass) PI 204433.

Toxin production. Cells were grown overnight in medium 523, and $1.5 \mathrm{ml}$ of the cell suspension (approximately $100 \mathrm{Klett}$ units) was added to $100 \mathrm{ml}$ of Wooley medium (45) in a 250-ml Erlenmeyer flask. Cultures were grown for 5 days at $24^{\circ} \mathrm{C}$ on a rotary shaker. Sterile culture filtrates were prepared by Millipore filtration using a $0.22-\mu \mathrm{m}$ sterile filter and injected into test plant species. Incubation was identical to that used for pathogenicity tests.

\section{RESULTS}

Morphology. Cells of $P$. coronafaciens C-28, $P$. coronafaciens C-107, $P$. coronafaciens subsp. atropurpurea $\mathrm{C}-136, P$. coronafaciens $\mathrm{C}-19$, and $P$. striafaciens $\mathrm{C}-137$ averaged 2.8 by $0.6,2.3$ by $0.8,2.3$ by $0.7,2.8$ by 1.0 , and 2.3 by $0.8 \mu \mathrm{m}$, respectively. Cells were rod-shaped with polar multitrichous flagella. A few cells of $P$. striafaciens $\mathrm{C}-137$ were slightly curved, and filaments were present in preparations of $P$. coronafaciens C-19 and C-28.

Physiological and biochemical properties. The characteristics of 22 strains are summarized in Table 2. No significant differences among strains of $P$. coronafaciens, $P$. coronafaciens pathovar zeae, $P$. coronafaciens subsp. atropurpurea, and $P$. striafaciens were evident.

Serology. The different strains of $P$. coronafaciens, $P$. coronafaciens pathovar zeae, $P$. coronafaciens subsp. atropurpurea, $P$. striafaciens, and Pseudomonas sp. could not be differentiated by agglutination or fluorescent antibody tests (Table 3 ). All the strains reacted equally with antiserum to cells of $P$. coronafaciens or $P$. coronafaciens subsp. atropurpurea. Two other pseudomonads, $P$. cepacia and $P$. fluorescens, gave cross-agglutination titers similar to those of $P$. coronafaciens. However, no other pseudomonad gave a positive fluorescent antibody stain.

Host range. Individual strains differed in their pathogenicity and virulence on the 11 plant species tested. However, the only difference in host range that was detected among the strains of the supposed taxonomic groups was the failure of $P$. striafaciens strains to infect any plant species except oats (Tables 4 and 5).

Toxin production. Strains of $P$. coronafaciens, $P$. coronafaciens pathovar zeae, $P$. coronafaciens subsp. atropurpurea, and Pseudomonas sp. from timothy produced toxin which caused the typical halo chlorosis on most test 
TABLE 2. Phenotypic characters of Pseudomonas coronafaciens, $P$. coronafaciens pathovar zeae, $P$. coronafaciens subsp. atropurpurea, and P. striafaciens ${ }^{a}$

\begin{tabular}{|c|c|c|c|c|}
\hline Characteristic & $\begin{array}{l}\text { P. coronafa- } \\
\text { ciens }(N=11)\end{array}$ & $\begin{array}{l}\text { P. coronafaciens pa- } \\
\text { thovar zeae }(N=4)\end{array}$ & $\begin{array}{l}\text { P. coronafaciens subsp. } \\
\text { atropurpurea }(N=6)\end{array}$ & $\begin{array}{l}\text { P. striafaciens } \\
(N=2)\end{array}$ \\
\hline \multicolumn{5}{|l|}{ Utilization of: } \\
\hline Sucrose & + & + & + & + \\
\hline Glycerol & + & + & + & + \\
\hline D-Glucose & + & + & + & + \\
\hline D-Fructose & + & + & + & + \\
\hline Capric acid & + & + & + & + \\
\hline Mannitol & $\mathrm{V}(7+)$ & + & + & + \\
\hline D-Mannose & $V(7+)$ & + & + & + \\
\hline Citrate & + & $\mathrm{V}(2+)$ & + & + \\
\hline L-Erythritol & $V(8+)$ & $v(3+)$ & $V(4+)$ & + \\
\hline Maltose & $V(6+)$ & $v(3+)$ & \pm & \pm \\
\hline Inositol & $V(6+)$ & + & + & + \\
\hline L-Ascorbic acid & \pm & \pm & \pm & - \\
\hline L-Rhamnose & - & - & - & - \\
\hline D-Cellobiose & - & - & - & - \\
\hline$\beta$-Alanine & - & - & - & - \\
\hline L-Tartaric acid & - & - & - & - \\
\hline L-Arabinose & - & - & - & - \\
\hline Lactose & - & - & - & - \\
\hline Ethanol & - & - & - & - \\
\hline Ethanolamine & - & - & - & - \\
\hline$n$-Propanol & - & - & - & - \\
\hline L-Leucine & - & - & $V(1+)$ & - \\
\hline D-Serine & \pm & \pm & \pm & \pm \\
\hline \multicolumn{5}{|l|}{ Growth at: } \\
\hline $0^{\circ} \mathrm{C}$ & + & + & + & + \\
\hline $41^{\circ} \mathrm{C}$ & - & - & - & - \\
\hline \multicolumn{5}{|l|}{ Growth on: } \\
\hline HE agar & $V(7+)$ & + & $V(4+)$ & + \\
\hline MacConkey agar & + & + & + & + \\
\hline Salmonella-shigella agar & $V(7+)$ & ND & $\mathrm{V}(2+)$ & ND \\
\hline \multicolumn{5}{|l|}{ Growth in: } \\
\hline $\mathrm{NB}-\mathbf{5} \% \mathrm{NaCl}$ & \pm & \pm & \pm & \pm \\
\hline $\mathrm{NB}-7 \% \mathrm{NaCl}$ & - & - & $=$ & $=$ \\
\hline Lipid hydrolysis & + & + & + & + \\
\hline Litmus milk & Alk & Alk & Alk & Alk \\
\hline Melanin pigment production & + & + & + & + \\
\hline Fluorescent pigment production & + & + & $\mathrm{V}(5+)$ & + \\
\hline Gelatin hydrolysis & $\mathrm{V}(6+)$ & $\mathrm{V}(3+, 1 \pm)$ & $\mathrm{V}(1 \pm)$ & - \\
\hline Lecithinase & $V(5+)$ & $\mathrm{V}(3+)$ & $\mathrm{V}(2+)$ & + \\
\hline Malonate & - & V (3 Alk) & $V(3+)$ & - \\
\hline Arginine dihydrolase & - & - & - & - \\
\hline Nitrate reduction & - & - & - & - \\
\hline Starch hydrolysis & - & - & - & - \\
\hline Oxidase production & - & - & - & - \\
\hline
\end{tabular}

${ }^{a}$ Symbols and abbreviations: + , test was positive; - , test was negative; \pm , weak or no response after 5 days, positive after 14 days; Alk, alkaline; V, variable; numerals indicate number of strains positive $(+)$ or weak $( \pm)$; NB, Difco nutrient broth; ND, not determined.

plants (Table 4). The three strains of $P$. coronafaciens subsp. atropurpurea from Japan and $P$. striafaciens did not yield detectable haloinducing toxin from culture filtrates.

\section{DISCUSSION}

The phenotypic relationship among the plant pathogenic fluorescent pseudomonads has been studied in recent years by Lelliott et al. (18), Misaghi and Grogan (23), and Sands et al. (33). Although these workers were able to differentiate plant pathogens from saprophytic pseudomonads, they were unable to differentiate the many species of plant pathogenic pseudomonads. In the 8th edition of Bergey's Manual (5), all plant pathogenic pseudomonads have been 
TABLE 3. Tube agglutination titers and fluorescent antibody staining with antisera to strains C-107 and C- 136

\begin{tabular}{|c|c|c|c|c|c|}
\hline \multirow{2}{*}{ Antigen } & \multirow{2}{*}{ Strain } & \multicolumn{2}{|c|}{ Agglutination titers ${ }^{a}$} & \multicolumn{2}{|c|}{ FA staining ${ }^{b}$} \\
\hline & & C-107 & C-136 & C-107 & C-136 \\
\hline P. coronafaciens & C-28 & 160 & 80 & +3 & +3 \\
\hline$P$. coronafaciens & C-72 & 160 & 320 & +1 & +2 \\
\hline P. coronafaciens & C-81 & 80 & 80 & +3 & +3 \\
\hline P. coronafaciens & C-83 & 160 & 320 & +3 & +3 \\
\hline P. coronafaciens & C-107 & 80 & 80 & +3 & +2 \\
\hline$P$. coronafaciens & C-19 & 40 & 80 & +2 & +3 \\
\hline P. coronafaciens pathovar zeae & C-162 & 80 & 320 & +2 & +2 \\
\hline$P$. coronafaciens pathovar zeae & C-163 & 80 & 160 & +2 & +2 \\
\hline P. coronafaciens pathovar zeae & C-164 & 40 & 160 & +2 & +2 \\
\hline P. coronafaciens pathovar zeae & C-165 & 40 & 160 & +2 & +2 \\
\hline P. coronafaciens subsp. atropurpurea & C-82 & 640 & 80 & +2 & +2 \\
\hline$P$. coronafaciens subsp. atropurpurea & C-136 & 40 & 80 & +3 & +2 \\
\hline P. coronafaciens subsp. atropurpurea & C-142 & 80 & 320 & +3 & +2 \\
\hline$P$. coronafaciens subsp. atropurpurea & C-159 & 40 & 640 & +3 & +3 \\
\hline$P$. coronafaciens subsp. atropurpurea & C-160 & 640 & 320 & +3 & +3 \\
\hline P. coronafaciens subsp. atropurpurea & C-161 & 40 & 160 & +3 & +3 \\
\hline$P$. striafaciens & C-137 & 320 & 80 & +1 & +2 \\
\hline$P$. striafaciens & C-174 & 40 & 80 & +3 & +3 \\
\hline Pseudomonas sp. & C-80 & 80 & 80 & +3 & +3 \\
\hline$P$. syringae & C-7 & - & - & - & - \\
\hline$P$. andropogonis & C-18 & - & - & - & - \\
\hline P. andropogonis & C-78A & - & - & - & - \\
\hline P. lachrymans & C-50 & - & - & - & - \\
\hline$P$. aeruginosa & C-91 & - & - & - & - \\
\hline P. cepacia & C-92 & 40 & 10 & - & - \\
\hline$P$. fluorescens & C-94 & 160 & 80 & - & - \\
\hline P. setariae & C-132 & 10 & 10 & - & - \\
\hline
\end{tabular}

${ }^{a}$ Values given are reciprocals of highest dilution that showed agglutination; - indicates no agglutination at lowest dilution tested (1:10).

${ }^{b}$ FA, Fluorescent antibody. The intensity of the fluorescence was classified from (-) to +3 , with (-) representing no visible fluorescence and +3 indicating intense fluorescence.

placed into eight nomenspecies. Pecknold and Grogan (29), using deoxyribonucleic acid-deoxyribonucleic acid hybridization, grouped 18 species including $P$. coronafaciens into four distinct genotypic groups, "syringae," "morsprunorum," "viridiflava," and "cichorii," and two artificial groups (due to insufficient data), "tomato" and "marginalis." Pseudomonas coronafaciens was included in their group "tomato." Pseudomonas coronafaciens showed less than $60 \%$ homology to $P$. syringae, $P$. aptata, $P$. morsprunorum, $P$. phaseolicola, $P$. cichorii, and $P$. viridiflava. DNA relatedness values of $70 \%$ or higher are considered an indication that the strains belong to the same species (4).

The 24 strains of bacteria studied here conform to the original description of $P$. coronafaciens (10). Colony types varied somewhat but were within the range described for the species.

Results of our physiological tests with $P$. coronafaciens agreed with the results of Sands et al. (33), using strains of $P$. coronafaciens NCPPB 1351, 1355, and $600, P$. delphinii NCPPB 650, P. dysoxylii NCPPB 225, P. garcae
NCPPB 1399, P. atrofaciens NCPPB 117, and $P$. glycinea UMPP R1 (Department of Plant Pathology, University of Minnesota, St. Paul), except for one test, utilization of arabinose. Whereas Sands et al. (33) reported that all strains in the $P$. coronafaciens group (listed above) utilized arabinose, we found that none of our strains utilized the substrate.

Furthermore, our results of physiological tests with $P$. striafaciens confirms an earlier description of one of the same strains (Pl-19-1). Tominaga and Nishiyama (44) compared an unknown organism causing a stripe blight of oats in Japan to $P$. coronafaciens using 30 bacteriological characters and found the two organisms to be indistinguishable. The only difference between the two organisms was the failure of the stripe blight organism (strain $\mathrm{Pl}$-19-1) to produce fluorescein pigment on $\mathrm{KB}$ medium. Because strain Pl-19-1 caused linear but not halo lesions in oats, and on the basis of results in an earlier report (11), they concluded that $\mathrm{Pl}-19-1$ was $P$. striafaciens and not $P$. coronafaciens. Our results agree completely except that we did ob- 
TABLE 4. Host range of halo blight pathogens on cereals and grasses ${ }^{a}$

\begin{tabular}{|c|c|c|c|c|c|c|c|}
\hline Strain & $\begin{array}{c}\text { Rye } \\
\text { (Secale } \\
\text { cereale) }\end{array}$ & $\begin{array}{c}\text { Oats } \\
\text { (Avena } \\
\text { sativa) }\end{array}$ & $\begin{array}{c}\text { Wheat } \\
\text { (Triticum } \\
\text { aestivum) }\end{array}$ & $\begin{array}{c}\text { Barley } \\
\text { (Hordeum } \\
\text { vulgare) }\end{array}$ & $\begin{array}{c}\text { Quackgrass } \\
\text { (Agropyron } \\
\text { repens) }\end{array}$ & $\begin{array}{l}\text { Timothy } \\
\text { (Pheleum } \\
\text { pratense) }\end{array}$ & $\begin{array}{c}\text { Maize } \\
(\text { Zea } \\
\text { mays) }\end{array}$ \\
\hline \multicolumn{8}{|c|}{$P$. coronafaciens } \\
\hline C-19 &,$+ \ln$ & $\ln$ & - &,$++ \ln$ & - & + & - \\
\hline $\mathrm{C}-20$ & $\mathrm{sl}$ &,$+ \ln$ & - & - & - & - & - \\
\hline $\mathrm{C}-23$ & +++ & +++ & + & - & ND & + & - \\
\hline $\mathrm{C}-28$ & +++ & +++ & sl & + & ++ & + & - \\
\hline C-64 & +++ & +++ & + & ++ & sl & + & - \\
\hline C-73 & + & + & sl & + & + & + & - \\
\hline C-80 & ++ & ++ & + & - & sl & ++ & - \\
\hline C-83 & - & - & - & - & ND & - & - \\
\hline C-86 & +++ & + & $++t$ & ++ & ND & - & - \\
\hline C-107 & +++ & +++ & sl & ++ & + & + & - \\
\hline \multicolumn{8}{|c|}{$\begin{array}{l}P . \text { coronafaciens pa- } \\
\text { thovar zeae }\end{array}$} \\
\hline C-162 & - & +++ & - & - & +++ & ++ & + \\
\hline C-163 & +++ & - & - & + & $+t+$ & +++ & +++ \\
\hline C-164 & sl & +++ & - & - & +++ & sl & ++ \\
\hline C-165 & - & sl & - & - & +++ & ++ & +++ \\
\hline \multicolumn{8}{|c|}{$\begin{array}{l}\text { P. coronafaciens } \\
\text { subsp. atropur- } \\
\text { purea }\end{array}$} \\
\hline C-82 & + & ++ & - & - & sl & + & - \\
\hline C-136 & - & +++ & - & - & + & ++ & - \\
\hline C-142 & sl & ++ & sl & sl & sl & sl & sl \\
\hline C-159 & ++ & ++ & sl & - & - & sl & + \\
\hline C-160 & ++ & + & + & - & - & sl & + \\
\hline C-161 & +++ & + & - & - & - & sl & + \\
\hline \multicolumn{8}{|l|}{ P. striafaciens } \\
\hline C-137 & - & $\ln$ & - & - & - & - & - \\
\hline C-174 & - & $\ln$ & - & - & - & - & - \\
\hline
\end{tabular}

a Symbols and abbreviations: + , halo 1 to $3 \mathrm{~mm}$ in diameter;,++ 3 to $7 \mathrm{~mm}$ in diameter;,$+++>7 \mathrm{~mm}$ in diameter; In, linear necrosis; sl, slight halo; -, no symptoms; ND, not determined.

serve the presence of a fluorescent pigment when individual colonies were observed under an ultraviolet light. We do not agree that such minor differences warrant creating a new ppecies, however.

Tominaga (42) found minor physiological differences among strains of bacteria causing bacterial blight of ryegrasses, fescues, and bromegrasses. Because the strains infected all three plant species he considered them all to be $P$. coronafaciens subsp. atropurpurea. In further tests, one strain from Italian ryegrass infected a wide range of small grains and other grasses, including oats and rye. Tominaga's results are consistent with the host range data presented here. Tessi (40) also reported a wide host range for a $P$. coronafaciens strain from oats. Among the susceptible hosts were rye and smooth bromegrass.

Tessi (40) presented convincing evidence that strains of $\boldsymbol{P}$. striafaciens were $\boldsymbol{P}$. coronafaciens strains that had lost the ability to produce toxin.
After 50 subcultures of a strain of $P$. coronafaciens, the ability to produce toxin was lost, and the symptoms produced on oats were identical to those caused by $P$. striafaciens.

Although we found that three strains of $P$. coronafaciens subsp. atropurpurea (C-159, C160 , and C-161) also failed to produce any detectable toxin in Wooley medium, they were similar to $P$. coronafaciens in all other characters. Furthermore, symptom expression on susceptible hosts was similar to the other strains of $P$. coronafaciens subsp. atropurpurea that we tested, which did produce toxin in Wooley medium. Whether or not the strains that failed to produce toxin in Wooley medium should be designated as separate biovars will require further characterization of their toxins.

Pseudomonas coronafaciens subsp. atropurpurea was described on the basis that strains of $P$. coronafaciens from oats did not infect smooth bromegrass, whereas those from smooth bromegrass were able to infect oats (31). Simi- 
TABLE 5. Host range of halo blight pathogens on Bromus species ${ }^{\alpha}$

\begin{tabular}{|c|c|c|c|c|}
\hline Strain & $\begin{array}{c}\text { Smooth brome } \\
\text { (B. inermis) }\end{array}$ & $\begin{array}{c}\text { Japanese brome } \\
\text { (B. japonicus) }\end{array}$ & $\begin{array}{l}\text { Chess brome } \\
\text { (B. secalinus) }\end{array}$ & $\begin{array}{c}\text { Cheatgrass } \\
\text { (B. tectorum) }\end{array}$ \\
\hline \multicolumn{5}{|l|}{$P$. coronafaciens } \\
\hline $\mathrm{C}-28$ & ++ & ++ & ++ & ++ \\
\hline C-73 & + & + & + & + \\
\hline $\mathrm{C}-80$ & + & ++ & ++ & ++ \\
\hline C-86 & ++ & ++ & ++ & ++ \\
\hline C-107 & +++ & - & + & + \\
\hline \multicolumn{5}{|c|}{$P$. coronafaciens pathovar zeae } \\
\hline C-162 & +++ & +++ & +++ & +++ \\
\hline C-163 & +++ & ++ & +++ & +++ \\
\hline C-164 & +++ & ++ & +++ & ++ \\
\hline C-165 & +++ & +++ & +++ & +++ \\
\hline \multicolumn{5}{|c|}{ P. coronafaciens subsp. atropurpurea } \\
\hline C-82 & + & + & ++ & - \\
\hline C-136 & ++ & ++ & ++ & + \\
\hline C-142 & ++ & ++ & ++ & ++ \\
\hline C-159 & +++ & +++ & +++ & +++ \\
\hline C- 160 & ++ & ++ & +++ & +++ \\
\hline C-161 & + & +++ & ++ & +++ \\
\hline \multicolumn{5}{|l|}{ P. striafaciens } \\
\hline C-137 & - & - & - & - \\
\hline C-174 & - & - & - & - \\
\hline
\end{tabular}

${ }^{a}$ Symbols: - , no infection; + , halos 1 to $3 \mathrm{~mm}$ in diameter;,++ 3 to $7 \mathrm{~mm}$ in diameter;,$+++>7 \mathrm{~mm}$ in diameter.

larly, $P$. coronafaciens pathovar zeae was described on the basis that strains of $P$. coronafaciens failed to infect corn and the new organism failed to infect oats. However, we found that, with the exception of corn, $P$. coronafaciens pathovar zeae infected the same hosts as $P$. coronafaciens. To create a pathovar or subspecies on such small differences would create chaos in bacterial taxonomy. On the other hand, there is some merit in considering $P$. striafaciens a pathovar of $P$. coronafaciens, since it infected only a single common host and produced very distinct symptoms on that host. However, until additional strains are available for study we feel that pathovar status is unwarranted.

Serological techniques have recently shown promise for identifying pseudomonads, including $P$. atrofaciens (28), $P$. fuscovaginae (38), $P$. lachyrmans $(21,37$; R. G. Grogan, L. T. Lucus, and K. Kimble, Phytopathology 55:1060, 1965), $P$. phaseolicola (14, 39; Grogan et al., Phytopathology 55:1060, 1965), P. pseudoalcaligenes subsp. citrulli (34), $P$. solanacearum $(8,24,30)$, $P$. syringae $(20,22,25,26), P$. tabaci $(19), P$. avenae (43), and $P$. andropogonis (43). The present study reveals that antiserum to cells of $P$. coronafaciens contains heteroagglutinins to $P$. fluorescens and P. cepacia. With these exceptions, agglutination tests with the various pseu- domonads (Table 3) were highly specific. Fluorescent antibody staining was highly specific. No cross-reaction with another pseudomonad was observed. The failure of our antiserum to $P$. coronafaciens and $P$. coronafaciens var. atropurpurea to react with $P$. andropogonis agrees with a previous report that antiserum to $P$. andropogonis failed to react with $P$. coronafaciens var. atropurpurea (43).

Because of the variability in virulence of strains of $P$. coronafaciens, it is important to inoculate oats, corn, and a Bromus sp. Pathogenicity on any one of the above hosts would suggest $P$. coronafaciens; however, identification should be confirmed by serology, preferably indirect immunofluorescent staining.

As evident from the data presented in Tables 2 through 5 , there are only minor differences among $P$. coronafaciens, $P$. coronafaciens pathovar zeae, $P$. coronafaciens subsp. atropurpurea, and $P$. striafaciens. Therefore, we regard all these names as subjective synonyms.

Pseudomonas coronafaciens, being the earliest name, has priority and is therefore the correct name of this species; $P$. coronafaciens subsp. atropurpurea and $P$. striafaciens become junior synonyms of $P$. coronafaciens. The neotype strain of $P$. coronafaciens is strain ATCC 19607 (C-28). Whether or not $P$. coronafaciens 
should be included with or is a synonym of another established Pseudomonas species will await more detailed studies.

\section{ACKNOWLEDGMENTS}

We thank Ruth C. Donaldson and John Youmans for technical assistance; R. W. Goth and S. S. Hearon (U.S. Department of Agriculture, Beltsville, Md.) for preparing electron micrographs which were used for cell morphology characterization; R. L. Clark (U.S. Department of Agriculture, Ames, Iowa), K. T. Leath (U.S. Department of Agriculture, University Park, Pa.), D. D. Morey (University of Georgia, Tifton), and Northrup-King \& Co. (Minneapolis, Minn.) for supplying seed samples; and R. E. Weaver (Center for Disease Control, Atlanta, Ga.), K. Nishiyama (National Institute of Agricultural Science, Tokyo, Japan), and R. D. Durbin (University of Wisconsin, Madison) for bacterial cultures.

\section{REPRINT REQUESTS}

Address reprint requests to: N. W. Schaad, Department of Plant Pathology, Georgia Experiment Station, Experiment, GA 30212.

\section{LITERATURE CITED}

1. Ad Hoc Committee of Judicial Commission of the ICSB. 1976. First draft. Approved lists of bacterial names. Int. J. Syst. Bacteriol. 26:563-599.

2. Blenden, P. C., and H. S. Goldberg. 1965. Silver impregnation strain for Leptospira flagella. J. Bacteriol. 89:899-900.

3. Breed, R. S., E. G. D. Murray, and N. R. Smith (ed.). 1957. Bergey's manual of determinative bacteriology, 7th ed. The Williams \& Wilkins Co., Baltimore.

4. Brenner, D. J., A. G. Steigerwalt, G. V. Miklos, and G. R. Fanning. 1973. Deoxyribonucleic acid relatedness among erwiniae, and other Enterobacteriaceae: the soft rot organisms (genus Pectobacterium Waldee). Int. J. Syst. Bacteriol. 23:205-216.

5. Buchanan, R. E., and N. E. Gibbons (ed.). 1974. Bergey's manual of determinative bacteriology, 8th ed. The Williams \& Wilkins Co., Baltimore.

6. Carpenter, P. L. 1975. Immunology and serology, 3rd ed. W. G. Saunders Co., Philadelphia.

7. Colwell, R. R. 1964. A study of features of diagnosis of Pseudomonas aeruginosa. J. Gen. Microbiol. 37:181194.

8. Digat, B., and M. Cambra. 1976. Specificity of antigens in Pseudomonas solanacearum E. F. Smith and application of serology for studying bacterial wilt, p. 38-57. In $\mathrm{L}$. Sequeira and A. Kemelman (ed.), Proceedings of the First International Planning Conference and Workshop on Ecology and Control of Bacterial Wilt Caused by Pseudomonas solanacearum. North Carolina State University, Raleigh.

9. Edwards, P. R., and W. H. Ewing. 1962. Identification of Enterobacteriaceae. Burgess Publishing Co., Minneapolis.

10. Elliott, C. 1920. Halo-blight of oats. J. Agric. Res. 19:139172.

11. Elliott, C. 1927. Bacterial stripe of oats. J. Agric. Res. 35: 811-824.

12. French, E. R., and L. Sequeira. 1970. Strains of Pseudomonas solanacearum from Central and South America: a comparative study. Phytopathology 60:506-512.

13. Goldman, M. 1968. Fluorescent antibody methods, p. 157-158. Academic Press Inc., New York.

14. Guthrie, J. W. 1968. The serological relationship of races of Pseudomonas phaseolicola. Phytopathology 58:716717.

15. Kado, C. I., and M. G. Heskett. 1970. Selective media for isolation of Agrobacterium, Corynebacterium, Erwinia, Pseudomonas, and Xanthomonas. Phytopathology 60:969-976.

16. King, E. O., M. K. Ward, and D. E. Raney. 1954. Two simple media for the demonstration of pyocyanin and fluorescein. J. Lab. Clin. Med. 44:301-307.

17. Kiraly, Z., Z. Klement, F. Solymosy, and J. Voros. 1970. Methods in plant pathology. Akademiai Kiado, Budapest.

18. Lelliott, R. A., E. Billing, and A. C. Hayward. 1966. A determinative scheme for the fluorescent plant pathogenic pseudomonads. J. Appl. Bacteriol. 29:470-489.

19. Lovrekovich, L., and Z. Klement. 1961. Species-specific antigens of Pseudomonas tabaci. Acta Microbiol. Acad. Sci. Hung. 8:303-310.

20. Lovrekovich, L., Z. Klement, and W. J. Dowson. 1963. Serological investigation of Pseudomonas syringae and Pseudomonas morsprunorum strains. Phytopathol. Z 47:19-24.

21. Lucus, L. T., and R. G. Grogan. 1969. Serological variation and identification of Pseudomonas lachrymans and other phytopathogenic Pseudomonas nomenspecies. Phytopathology 59:1908-1912.

22. Mazzucchi, U. 1975. Vascular blackening in sugarbeet toproots caused by Pseudomonas syringae van Hall. Phytopathol. Z. 84:289-299.

23. Misaghi, I., and R. G. Grogan. 1969. Nutritional and biochemical comparisons of plant-pathogenic and saprophytic fluorescent pseudomonads. Phytopathology 59:1436-1450.

24. Morton, D. J., P. H. Dukes, and S. F. Jenkins, Jr. 1965. Serological identification of Pseudomonas solanacearum in four solanaceous hosts. Phytopathology 55: 1191-1193.

25. Opera, F. 1971. Serological investigations on bacteria Pseudomonas morsprunorum and Pseudomonas syringae. Rev. Roum. Biol. Ser. Bot. 16:213-220.

26. Otta, J. B., and H. English. 1971. Serology and pathogenicity of Pseudomonas syringae. Phytopathology 61: 443-452.

27. Palleroni, N. J., and M. Doudoroff. 1972. Some properties and taxonomic subdivisions of the genus Pseudomonas. Annu. Rev. Phytopathol. 10:77-78.

28. Pastushenko, L. T., I. B. Kovoleva, S. S. Sidorenko, and I. D. Dimonovich. 1976. Serological study of the pathogen of base bacteriosis in wheat. Sel'Skohoziaistvennaia Biol. (Moscow) 11:582-586.

29. Pecknold, P. C., and R. G. Grogan. 1973. Deoxyribonucleic acid homology groups among phytopathogenic Pseudomonas species. Int. J. Syst. Bacteriol. 23:111121.

30. Perez, J. E. 1964. The use of Fuller's formamide method in the serological identification of Pseudomonas solanacearum. J. Agron. Univ. Puerto Rico 45:144-153.

31. Reddy, C. S., and J. Godkin. 1923. A bacterial disease of bromegrass. Phytopathology 13:75-86.

32. Ribeiro, R. de L. D., R. D. Durbin, D. C. Arny, and T. F. Uchytil. 1977. Characterization of the bacterium inciting chocolate spot of corn. Phytopathology 67: 1427-1431.

33. Sands, D., M. N. Schroth, and H. G. H. Hildebrand. 1970. Taxonomy of phytopathogenic pseudomonads. J. Bacteriol. 101:9-23.

34. Schaad, N. W., G. Sowell, Jr., R. W. Goth, R. R. Cowell, and R. E. Webb. 1978. Pseudomonas pseudoalcaligenes subsp. citrulli subsp. nov. Int. J. Syst. Bacteriol. 28:117-125.

35. Stanier, R. Y., N. J. Palleroni, and M. Doudoroff 1966. The aerobic pseudomonads: a taxonomic study. J. Gen. Microbiol. 43:159-271.

36. Stapp, C. 1928. Scrauer's Handbuch der Pflanzenkrankheiten, vol. 2, p. 38-39.

37. Tanii, A., and T. Baba. 1973. Bacterial plant diseases in 
Hokkaido. III. Angular leaf spot of cucumber caused by Pseudomonas lachrymans (Smith et Byran) Carsner. Bull. Hokkaido Prefect. Agric. Exp. Sta. 28:70-78.

38. Tanii, A., K. Miyajima, and T. Akita. 1976. The sheath brown rot disease of rice plant and its causal bacterium, Pseudomonas fasucovaginae A. Tanii, K. Miyajima, et T. Akita. sp. nov. Ann. Phytopath. Soc. J. 42:540-548.

39. Taylor, J. D. 1971. Bacteriophage and serological methods for the identification of Pseudomonas phaseolicola (Burkh.) Dowson. Ann. Appl. Biol. 66:387-395.

40. Tessi, J. L. 1953. Comparative study of two bacteria pathogenic on oats and detection of a toxin which is the origin of their differences. Rev. Invest. Agric. B. Aires 7:131-145.

41. Thomason, B. M., and J. G. Wells. 1971. Preparation and testing of polyvalent conjugants for fluorescent antibody detection of Salmonellae. Appl. Microbiol. 22: 876-884.

42. Tominaga, T. 1968. Halo blight of ryegrasses, brome grasses and fescues. Ann. Phytopath. Soc. J. 34:242249.

43. Tominaga, T. 1971. Studies on the diseases of forage crops in Japan. Rep. Inst. Agric. (Japan) Ser. C 25:205306.

44. Tominaga, T., and K. Nishiyama. 1968. Bacterial strip blight of oats caused by Pseudomonas striafaciens (Elliott) Starr et Burkholder. J. Jpn. Soc. Grass. Sci. 14:51-55.

45. Wooley, D. W., R. B. Pringle, and A. C. Braun. 1952. Isolation of the phytopathogenic toxin of Pseudomonas tabaci, an antagonist of methionine. J. Biol. Chem. 197: 409-417. 